\title{
The Role of Therapy Education of Islamic Meaning to Overcome Global Human Crisis Today
}

\author{
Nina Aminah 1 \\ 1/slamic Education Institute of Health Sciences (STIKes) Budi Luhur, \\ Cimahi, Indonesia.
}

Email: aminahnina65@gmail.com

\begin{abstract}
:
Modern community today showed the current issues that related to the complexity of personality. Islam offers a therapeutic meaning to overcome the global human crisis through the holy Quran. The aim of this study is to provide a qualitative analysis of logo therapy alternative to global human being who has experience critical conditions such as for someone who becomes the door of death (Sakarat al-Maut), acute illnesses, HIV Aids, kidney illness, stroke, coma, depression or stress, due to the hazards, and the other refractory diseases. Through the Quranic analytical perspective, the result of this study showed that the therapy of Islamic meaning based on the holy Quran can be seen as the broader and more comprehensive than the meaning therapy by Viktor E. Frank's method.
\end{abstract}

Keywords: Modern, Community, Therapy, Complexity, Personality, Quranic Perspective.

\section{A. INTRODUCTION}

Personality psychology is not a new subject, but it has been studied by many experts with different terms. In Indonesian terminology personality psychology is sometimes defined as character science, characterology, personality theory, and personality psychology. The word character is used in a normative meaning when attitude, behavior and action are seen in terms of social norms whether it is good or not good (Suryabrata, 1986). According to growth or development psychologists that human personality is influenced by conflicts of childhood and even the influence of outside stimulus.

These conflicts occur everywhere, and even in developed countries global human crisis emerge. Humans are exposed to current issues related to the very complex personality. For example, Metro TV station Friday, July 24, 2015 revealed: that in every two weeks the blind shooting by teens / adults occured in the United State of America, and it even happened in schools and in theaters. All this problem is due to the life-meaning crisis of today's global human.

On the other hand, the images of growth psychologist of human are optimistic and hopeful. They believe in our capacity to expand, enrich, develop, and fulfill ourselves, to become everything that we wish. The supporters of the human potential movement suggested that there is an indispensable level of growth and development, that goes beyond the "normality", and they argued that humans need to fight for a more advanced level of growth in order to realize or actualize all their potential (Schultz, 1993). The best human potential must be fought for. 
The meaning of human existence and creation by God on the earth is just intended to worship Him. God the Almighty said in the holy Book "And I did not create the jinn and mankind except to worship Me. "(QS. Al-Dhāriyāt [51]: 56). The letter lām (pronounced li) li ya'budūn has the meaning of result, impact or termination. Thus, we do should any activity sincerely, which is meaningful to our life in the world and even rewarded in the hereafter later. That is the highest meaning of Muslim life stated in the holy Qur'an. Qur'an may functions as a guide of therapeutic education of Islamic meaning to deal with global human crisis.

\section{B. METHODS}

Logotherapy was first introduced by Viktor E. Frankl. Viktor E. Frankl is Professor of Neurology and Psychiatry at the University of Vienna Medical School and the senior Professor logotherapy at the US International University. He is an 'eastern' western psychologists, because Frank'sl idea about the meaning of life for everyone is not new to East spiritualist. We are familiar with the term Sufism, a word often associated with wisdom. Frankl had been in the death camp as a prisoner of the army of Nazi Germany for four years during World War II. The suffering experiences has been told in his famous book "Man's Search for Meaning" (Searching the Meaning of Life: essence of life, Meaning of Love, Meaning of Suffering).

Hanna Djumhana Bastaman stated that logotherapy is not closed to religion, but it provide opportunities to every person to fully realize the religious values as the source of the meaning of life. It is important to know that logotherapy view which recognizes spiriritual dimensions (Noetic) as a characteristic of humans is the first step towards the assessment of the religious spiritual dimension, which is so far untouched and (even) ignored by contemporary secular psychology. The way how to feel that life is still meaningful in any condition, Hanna Djumhana Bastaman describes the following scheme of happy-suffering in his book entitled Meraih Hidup Bermakna (Bastaman, 1996).

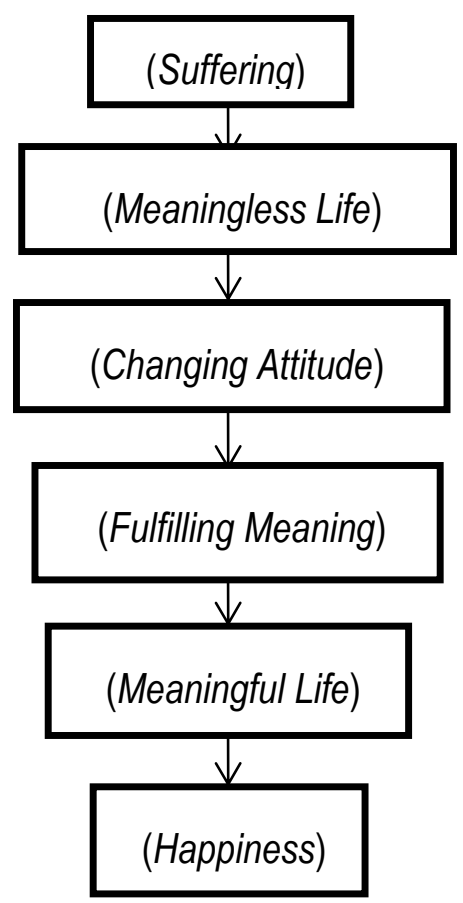

Figure 1: Process of Meaning Therapy from Suffering to Happiness 
Furthermore, Bastaman generally elaborated the core process described in the following schemes:

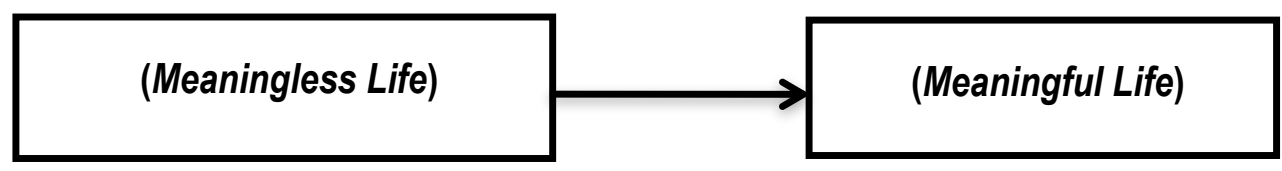

Figure 2: Transformations from Meaningless Life to Meaningful Life

\section{RESULT AND DISCUSSIONS}

\section{Meaning therapy (Logotherapy) by Viktor E. Frankl}

In this study, the theory used is the "logotherapy" of Viktor E. Frankl (2004). This is a personal experience of Frankl had been in the death camp as a prisoner of the army of Nazi Germany for four years during World War II, he was prisoner number 119104 (Frankl, 2004). He was a man who suddenly realized that, "he did not have anything except her naked and ridiculous life." Later, he designed a strategy to survive and maintain his life, although he had little possibility of survival.

Although starvation, humiliation, fear and deep anger with injustice happened to Frankl, he could deal with all of the problems by presenting imagination of loved peopel, with religion, sense of humor just by glance looking at nature --- tree or sun set. The main theme of existentialism: life is synonymous with suffering, survival is identical to finding meaning in suffering. Nonetheless, no one can show other people's meaning of life. Every person must find his own life goal.

\section{Islamic Meaning of Therapy Education}

Ibin Kutibin Tadjudin in his book Psikoterapi Holistik Islam (2007) stated, "A healthy soul is a soul that devote to Allah the Almighty. By devotion to Allah he will be able to cope with conflict, stress, and frustration adequately, with adapting, gaining achievement and producing something because he believes that human is only an executor, and final provision is Allah's. With giving trust to God, patience, sincerity with God's will and ingratitude, the balance of neurotransmitters in the brain will always be maintained, so that the soul will remain healthy." Criteria for a healthy life in Muslim's view: to feel comfortable with himself, to feel comfortable dealing with others, to meet the needs of life, feels comfortable and not burdened with the past, hard-working, able to manage the stress experienced, appreciate God's favors, independent and consistent, believe in a future hoping God's grace, the soul with management implementation of good deeds.

The following table shows the indicators of Islamic meaning therapy education according to the holy Qur'an to overcome the global human crisis and its relationship with Viktor E. Frankl's logotherapy.

Table 1: Indicators of Islamic Meaning Therapy Education according to holy Qur'an

\begin{tabular}{|c|l|l|l|}
\hline No. & \multicolumn{1}{|c|}{ Indicator } & \multicolumn{1}{|c|}{ Meaning therapy Islami } & \multicolumn{1}{c|}{$\begin{array}{c}\text { Logotherapy } \\
\text { Viktor E. Frankl }\end{array}$} \\
\hline 1. & Motivation of life & $\begin{array}{l}\text { Worship (QS. Al-Dhāriyāt [51]: } \\
\text { 56); just for Allah (QS. Al-An'ām } \\
\text { [6]: 162). }\end{array}$ & (meaning/logo) \\
\hline
\end{tabular}




\begin{tabular}{|c|l|l|l|}
\hline 2. & Focus of life & $\begin{array}{l}\text { The best community (QS. Ālu- } \\
\text { 'Imrān [3]: 110) }\end{array}$ & Awareness (existential) \\
\hline 3. & Past Orientation & $\begin{array}{l}\text { Fate, God who gives sustenance } \\
\ldots \text { written in Lauhmahfuz (QS. } \\
\text { Hūd [11]: 6) }\end{array}$ & No \\
\hline 4. & Today's Orientation & $\begin{array}{l}\text { Effort of "duniawi-ukhrawi" (QS. } \\
\text { Al-Qașaș [28]: 77); pray (QS. Al- } \\
\text { Baqarah [2]: 186) }\end{array}$ & Yes \\
\hline 5. & Future Orientation & $\begin{array}{l}\text { Die as Muslim (QS. Al-Baqarah } \\
\text { [2]: 132): tomorrow (QS. Al-Hasyr } \\
\text { [59]: 18) }\end{array}$ & Yes \\
\hline 6. & $\begin{array}{l}\text { Human nature } \\
\text { (Iogotherapy) }\end{array}$ & $\begin{array}{l}\text { Two ways (QS. Al-Balad [90]: 10- } \\
\text { 11); paradise (QS. Ālu-'Imrān [3]: } \\
\text { 195) }\end{array}$ & $\begin{array}{l}\text { Free to chose, willingnes of } \\
\text { meaning, meaningful life. }\end{array}$ \\
\hline 7 & Values of life & $\begin{array}{l}\text { Pray prevent evils } \\
\text { (QS. Ar Ra'd [29]: 45); enforching } \\
\text { belief (QS. Âlu-'Imrān [3]: 31) }\end{array}$ & $\begin{array}{l}\text { - Value of creativity (self- } \\
\text { actualization) } \\
\text { - Value of experience } \\
\text { - Value of attitude }\end{array}$ \\
\hline 8. & Value of love & $\begin{array}{l}\text { Mercy for natures (QS. Al-Anbiyā' } \\
\text { [21]: 107); we honor the children } \\
\text { of Adam (QS. Al-Isrā' [17]: 70) }\end{array}$ & $\begin{array}{l}\text { - Giving love } \\
\text { - Receiving love }\end{array}$ \\
\hline 9. & Meaning of suffering & $\begin{array}{l}\text { Fear, hunger,... (QS. Al-Baqarah } \\
\text { [2]: 155); doom and misery (QS. } \\
\text { Al-Baqarah [2]: 214); ...do not } \\
\text { despise the doomsday (QS. Ālu- } \\
\text { 'Imrān [3]: 194) }\end{array}$ & $\begin{array}{l}\text { - Tragedy, tragic and critical } \\
\text { - Empty }\end{array}$ \\
\hline
\end{tabular}

Based on the table above, the basic goals of human existence on the earth are, namely devotion ('abd), submission to God, and being caliphate on earth. To achieve that goal, Allah gives guidance as well as various facilities in this universe. God gives freedom to people to choose goodness or badness. Allah gives guidance to people in order to understand the purpose of their life, with sending His apostles (Aminah, 2014). The highest duty of human is to worship the God Allah. The holy Qur'an illustrates how humans should fulfill their duties, in the form of surrender to Allah (QS. AlAn'ām [6]: 162).

The primarily worship that has the highest values is prayer. According to Dhahabi, the prayer that bring certain changes in the physical attitude, has four benefits, namely spiritual, psychological, physical, and moral benefits : "Prayer can cure heart disease, stomach, and intestines. There are three reasons for this argument. First, prayer is a form of worship ordered by God. Second, prayer has psychological benefits because it can distract the mind from the pain by strengthening the power of repellent pain. The true prayer can collect a variety of ways beneficial to Muslim because prayer simultaneously instills fear, humiliation, love of God, and remembering judgment day. Third, in addition to the concentration of mind, there is also physical training in prayer. Prayer consists of a series of gestures, including upright, bowing, prostrating, relaxation, and concentration, as well as most of the organs are in relaxation" (Rahman, 1999).

After explaining in detail the physical benefits of various attitudes in prayer, Al-Dhahabi stated (Aminah, 2013): "Prayer often breeds happiness and peace of mind; eliminates anxiety and extinguish anger. Prayer increase the love for truth and modesty before human; soften heart, implants love, forgiveness, and extinguish revenge. In addition, clear thinking often comes to mind 
(because it concentrates on the complicated problem) and prayer can find the correct answer (to various problems). We are also reminded of something forgotten ... We can find some ways to resolve the temporal and spiritual problems. And we can test ourselves effectively, especially if we focus on prayer. The best prayer time is at the end of the night when people are asleep and atmosphere is silent. "

The human's submission provides an opportunity for them to get mandate, and responsibility from the Creator God. The obligation constitutes human's role as the caliph of God on earth. Suitability between the role and the mandate will be assessed positively, with a promise to obtain rewards (reward) from. Conversely, those who fulfill them will get negative judgement, and will get a penalty (punishment) because human beings are given the freedom to choose two paths, right (kindness) (Jalaludin, 2003) or the misguided (evils). "And have shown him the two ways?" (QS. Al-Balad [90]: 10).

Caliphate contains three main elements implied in above verse, namely: (1) human as caliph; (2) earth as human habitation; (3) Caliphate task assigned to him by God (Shihab, 2007). If so, the task of Caliphate requires performing the duty assigned corresponding to the instructions God who gave caliph the task and authority. God always motivate His people in the holy Qur'an to do good, be meaningful to many people, and provide blessing for the entire universe (QS. Al-Anbiyā' [21]: 107).

The following figure shows the diagram of Islamic meaning theraphy education according to the Holy Qur'an.

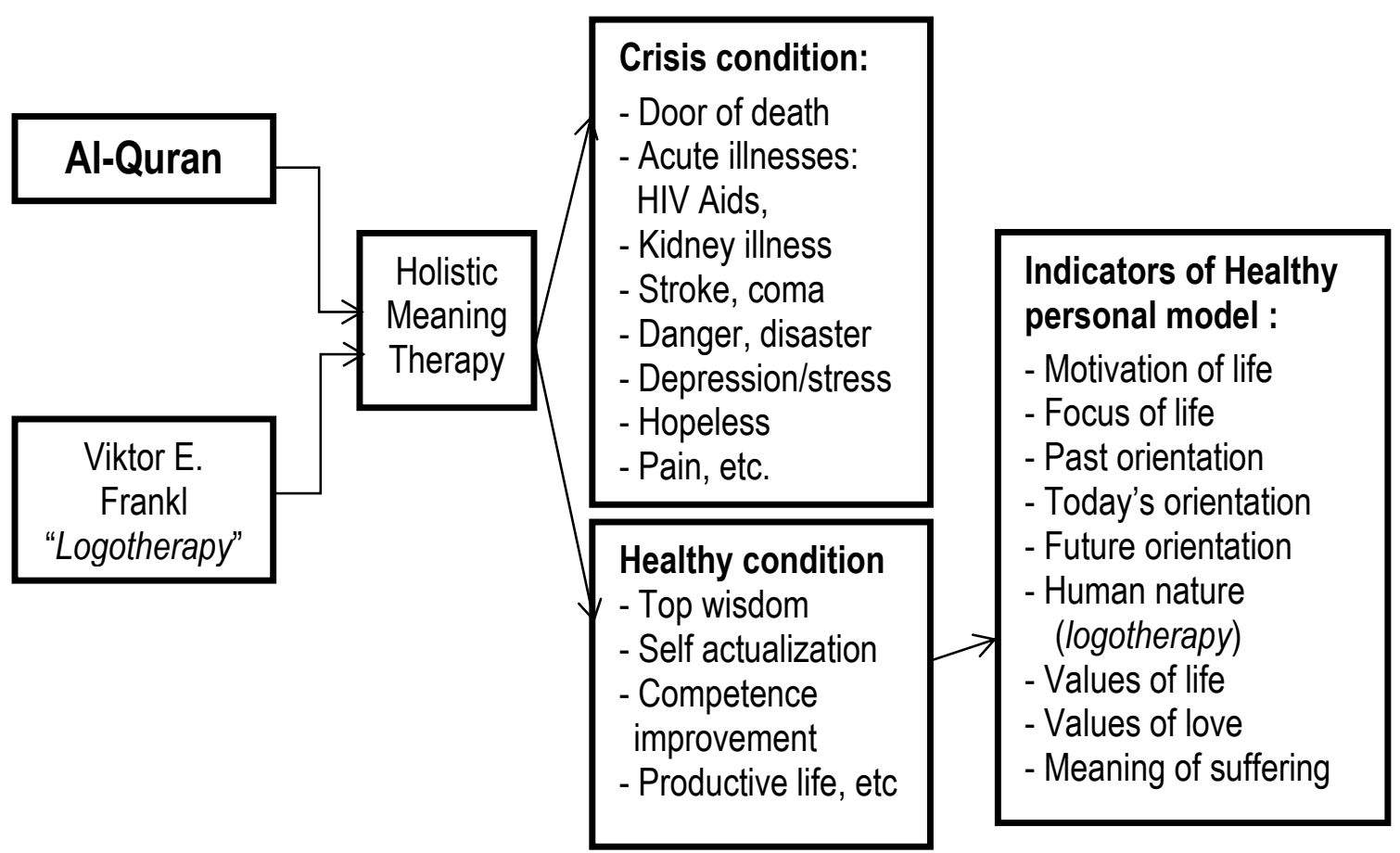

Figure 3: Islami Meaning Therapy Education

In fact, global human crisis are all events that take place due to Allah's permit and they have been defined in the Lawh Mahfouz (al-lawh al-mahfüz) laid in the law of nature. Humans often cause the crisis because of infidelity, hypocrisy, immorality, and at the same time they accept the consequences. Islam has given guide in addressing crises such as by saying istirjầ', praying, being 
patient and not despairing, accepting the crisis with not regreting it, not complicating ourselves, and making the crisis as an introspection moment (muhāsaba).

\section{CONCLUSION}

In overcoming the global human crisis, logotherapy is not closed to religion, bit it provides opportunities to every person to fully realize the religious values as the source of the meaning of life. It is important to know that the logotherapy views which recognizes the spiritual dimension (Noetic) as one characteristic of humans is the first step towards the assessment of the religious spiritual dimension, which is so far untouched and (even) be ignored by contemporary secular psychology.

In addition, Islamic meaning therapy education can overcome the crisis for global human through surrendering to Allah the Almighty. By full submittion to Allah it will be able to cope with conflict, stress, and frustration adequately, with adapting, gaining achievement and producing something because he believes that human is only an executor, and final provision is Allah's. With giving trust to God, patience, sincerity with God's will and ingratitude, the balance of neurotransmitters in the brain will always be maintained, so that the soul will remain healthy.

In all circumstances healthy or sick, global human are recommended to hold the holy book of life, namely the holy qur'anbecause the values of qur'anare the best solution that can respond all problems in human life in any time and situation. 


\section{References}

'Abdul Baqi, Muhammad Fu'ad. (1988). al-Mu'jam al-Mufahras li Alfāẓ al-Qur'ān al-Karīm, Qahirah: Dar al-Hadis.

Al Fanjari, Ahmad Syauqi. (1999), Nilai-nilai Kesehatan dalam Syariat Islam, Jakarta: Bumi Aksara.

Al-Ghazali, Syaikh Muhammad. (2008). Kayfa Nata'āmal ma' Al-Qurān, terj. Masykur Hakim dan Ubaidillah, Al-Quran Kitab Zaman Kita (edisi lama berjudul Berdialog dengan Al-Quran, 1996), Bandung: Khazanah.

Al-Jauziyah, Ibnu Qayyim Al-Jauziyah. (2010). Thibb al-Nabawī, terj. Abu Firly, Praktek Kedokteran Nabi, Yogyakarta: Hikam Pustaka.

Al-Qarni, Abdullah, Aidh. (2004). Lā Taḥzan, terj. Samson Rahman, Jangan Bersedih, Jakarta: Qisthi Press.

Al-Qarni, Abdullah, Aidh. (2005). Jangan Takut Hadapi Hidup, terj. Masrukhin, Hadā 'iq Dzatu Bahjah, Jakarta: Cakrawala Publishing.

Alibasyah, Permadi. (2011). Bahan Renungan Kalbu, Penghantar Mencapai Pencerahan Jiwa, Bandung: Cahaya Makrifat.

Amam, Chairul. et. al. (2004). Hadāiq Dzatu Bahjah, terj. Samson Rahman, Berbahagialah, Jakarta: Pustaka Al-Kautsar.

Amam, Chairul. et. al. (2008). Psikologi Qurani, Bandung: Cahaya Iman dan Bedha.

Aminah, Nina. (2013). Pendidikan Kesehatan dalam Al-Quran, Bandung: Remaja Rosdakarya.

Aminah, Nina. (2014). Studi Agama Islam untuk Perguruan Tinggi Kedokteran dan Kesehatan, Bandung: Remaja Rosdakarya.

Bastaman, Djumhana, Hanna. (1995). Intergasi Psikologi dengan Islam, Yogyakarta: Yayasan Insan Kamil dan Pustaka Pelajar.

Bastaman, Djumhana, Hanna. (2004). Meraih Hidup Bermakna, Jakarta: Paramadina. Viktor E., Frankl, Viktor E. Frangkl. Mencari Makna Hidup, Bandung: Nuansa.

Chaplin, J. P. (1999). Kamus Lengkap Psikologi, Jakarta: Raja Grafindo Persada.

Daradjat, Zakiah. (1969). Kesehatan Mental, Jakarta: PT Gunung Agung.

Daradjat, Zakiah. (1970). Peranan Agama dalam Kesehatan Mental, Jakarta: PT Gunung Agung.

Departemen Agama RI. (1998). Islam untuk Disiplin IImu Kedokteran dan Kebidanan I, Jakarta: Direktorat Kelembagaan Islam.

El-Quussy, 'Aziz, Abdul. (1974). Pokok-pokok Kesehatan Jiwa/Mental, Jakarta: Bulan Bintang. 
Fahmi, Musthafa. (1977). Kesehatan Jiwa: Dalam Keluarga, Sekolah, dan Masyarakat, Jilid I, Jakarta: Bulan Bintang.

Fahmi, Musthafa. (1977). Kesehatan Jiwa: Dalam Keluarga, Sekolah, dan Masyarakat, Jilid II, Jakarta: Bulan Bintang.

Frankl, Viktor E. (1985). Man's Search for Meaning, New York: Washington Square Press.

Frankl, Viktor E. (2004). Man's Search for Meaning, terj. Lala Hermawati Dharma, Mencari Makna Hidup, Bandung: Nuansa.

Goleman, Daniel dan Speeth, Riondar, Kathleen. (1993). The Essential Psychotherapies, terj. Essensial Psikoterapi: Terori dan Praktek Para Ahli, Semarang: Dahara Prize.

Hidayat, Komaruddin. (2006). Psikologi Kematian, Mengubah Ketakutan Menjadi Optimisme, Bandung: Hikmah.

Hidayat, Komaruddin. (2008). The Wisdom of Life, Menjawab Kegelisahan Hidup dan Agama, Nur Achmad. Jakarta: Kompas.

Hidayat, Komaruddin. (2010). Psikologi Beragama, Bandung: Hikmah.

Idries, Dadang Hawari. (2000). Pendekatan Kejiwaan bagi Penderita Sakit, dalam Sakit Menguatkan Iman, Uraian Pakar Medis dan Spiritual, Jakarta: Gema Insani Press.

Idries, Dadang Hawari. (2005). Bila Aku Sakit: Panduan Praktis Kerohanian Islam, Bandung: AlShafa.

Jalaluddin. (2003). Teologi Pendidikan, Jakarta: Raja Grafindo Persada.

Koswara, E. (1992). Logoterapi Psisikoterapi Viktor Frankl, Yogyakarta: Kansius.

Kutibin, Ibin, Tadjudin. (2007). Psikoterapi Holistik Islam, Bandung: Kutibin.

Linschoten dan Mansyur. (1983). Pengantar IImu Jiwa: Ajaran Fungsi Umum (Fenomenologi), Bandung: Jemmars.

Mahmud, Ali Abdul Halim. (2004). Pendidikan Ruhani, Jakarta: Gema Insani.

Najati, Muhammad Utsman. (2005). Psikologi dalam Al-Quran, Terapi Qurani dalam Penyembuhan Gangguan Kejiwaan, Bandung: Pustaka Setia.

O'Brien, Elizabeth, Mary. (2011). Spirituality in Nursing: Standing on Holy Ground, Washington: Jones \& Bartlett.

Pedak, Mustamir. (2010). Quranic Super Healing: Sembuh dan Sehat dengan Mukjizat Al-Quran, Semarang: Pustaka Nuun.

Rahman, Afzalur. (2007). Quranic Sciences, terj. Taufik Rahman, Ensiklopediana IImu dalam AlQuran, Bandung: Mizania. 
Rahman, Fazlur. (1983). Major Themes of the Quran, terj. Anas Mahyuddin, Tema Pokok Al-Quran, Bandung: Pustaka.

Rahman, Fazlur. (1986). Teori-teori Kepribadian, Bandung: Eresco.

Rahman, Fazlur. (1987). Psikologi Eksistensial, Suatu Pengantar, Bandung: Rosda.

Rahman, Fazlur. (1999). Etika Pengobatan Islam, Penjelajahan Seorang Neomodernis, Bandung: Mizan.

Sani, Rahman. (2002). Hikmah Zikir dan Doa: Tinjauan IImu Kesehatan, Jakarta: Al-Mawardi Prima.

Schultz, Duane, Growth. (1993). Psychology: Models of the Health Personality, terj: Yustinus, Psikolog Pertumbuhan: Model-model Kepribadian Sehat, Yogyakarta: Kanisius.

Shihab, M. Quraish. (2007). Secercah Cahaya Ilahi: Hidup Bersama Al-Quran, Bandung: Mizan.

Washfi, Muhammad. (2008). Menguak Rahasia IImu Kedokteran dalam Al-Quran, Surakarta: Indiva Pustaka. 
The Role of Therapy Education of Islamic Meaning to Overcome Global Human Crisis Today 